\title{
Symbolic and Verbal Representation Process of Student in Solving Mathematics Problem Based Polya's Stages
}

\author{
Rahmad Bustanul Anwar ${ }^{1} \&$ Dwi Rahmawati ${ }^{1}$ \\ ${ }^{1}$ Mathematics Education, University of Muhammadiyah Metro, Indonesia \\ Correspondence: Rahmad Bustanul Anwar, Mathematics Education, University of Muhammadiyah Metro, \\ Indonesia. E-mail: rarachmadia@gmail.com
}

Received: April 27, 2017

doi:10.5539/ies.v10n10p20
Accepted: May 29, $2017 \quad$ Online Published: September 28, 2017

URL: https://doi.org/10.5539/ies.v10n10p20

\begin{abstract}
The purpose of this research was to reveal how the construction process of symbolic representation and verbal representation made by students in problem solving. The construction process in this study referred to the problem-solving stage by Polya covering; 1) understanding the problem, 2) devising a plan, 3) carrying outthe plan, and 4) looking back. This research was qualitative research by getting involved 4 students of Junior High School class VIII. This study obtained results that the construction process of symbolic representation made by students since in the process of understanding the problem. In understanding the problem, students were able to identify the problem well. Then students could make the symbol used as a variable that the value was not known. By using the symbol students could perform a series of calculation to obtain the value of the symbol. Symbols created by students were very helpful and facilitated students in solving problems. While in the construction process, verbal representation was done by students since the process of understanding the problem. The form of verbal representation was manifested by writing down all information known from a slightly changed problem because they used a language that they understood more. Based on the known information, students could plan and performed a series of calculations using written sentences so that the problems could be solved properly.
\end{abstract}

Keywords: representation, symbolic representation, verbal representation, problem solving

\section{Introduction}

National Council of Teachers of Mathematics (2000) set five standard processes that must be mastered by students such as representation. Mathematics is an abstract science. Mathematics really needs representation because one can get mathematical ideas that one of them is through representation (Kilpatrick, Swafford, \& Findell, 2001). Through representation students can make mathematical ideas to be more concrete and facilitate to do reflection (NCTM, 2000). Even the representation is seen as an important part of mathematical activity and means to capture mathematical concepts (Cobb et al., 2002; Cobb, 2003; Gravemeijer et al., 2003; Meira, 2003; Kaput et al., 2008; Cai, 2005; Anwar et al., 2016).

Student success in solving the problem is not out of the representation role (Akkus \& Cakiroglu, 2006; Hwang et al., 2007; Delice \& Sevimli 2010; Bal, 2014; Boonen et al., 2014). Thus, the mathematical problem solving using representation is strongly recommended because it can be used as a tool to facilitate during the problem solving process (Stylianou 2008). Schoenfeld (in Stylianou, 2010) calls representation as a means to understand the information obtained in problem situations. Newell and Simon (1972) see that representations can be as a means of recording while Stylianou and Silver (2004) call representation as a tool that facilitates the exploration of concepts or problems. In addition Gibson (1998) and Izsak (2003) view representation as a means of monitoring and evaluation to assess progress in solving problems.

Representation is a form of ideas disclosure embodied using various means such as spoken language, written language, symbols, drawings, diagrams, models, graphs, or using physical thing (Goldin, 2002). Representation can arise as a result of an individual response to a problem he faces. The resulted representation is strongly influenced by one's learning experience (Hutagaol, 2013), so if some people are faced the same problem then it is possible to obtain several different representations.

According to Goldin and Steingold (2001) there are two systems of representation namely external representation system and internal representation system. External representation system includes a conventional 
representation which is usually symbolically while internal representation system is created in one's mind and used to define mathematical meanings. Villages et al. (2009) mention the types of external representations namely: 1) verbal representation; it is fundamentally expressed in writing or speech.2) Pictorial representation; Including images, diagrams or graphs, as well as some interrelated activities.3) Symbolic Representation; Consisting of numbers, operations and connection signs, algebraic symbols and some interconnected actions.

Several studies have been conducted to see the kinds of representations that are effective in solving the problem (Çelik \& Arslan, 2012; Boonen et al., 2014; Dündar, 2015). These researches specifically describe the construction process of symbolic and verbal representations done by students in problem solving. Problem solving in this research referred to the problem solving stages by Polya (1973) which include: 1) Understanding the problem: understanding all the words in the problem. 2) Devising a plan: making a strategy to solve the problem in the form of guessing, drawing, looking for patterns, modeling. 3) Carrying out the plan: applying the selected strategy so the problem can be solved. 4) Looking back: reconsidering the whole process of problem solving. So that it will get the picture of symbolic and verbal representation process in problem solving.

\section{Method}

This research revealed how the construction process of symbolic representation and verbal representation were done by students in problem solving. So that through this study will illustrate the construction process theory of symbolic representation and verbal representation. According to Cresswell (2012) this research was qualitative research. In this study involving 4 Junior High School students of class VIII, used as a research subject. 4 students as the subject of the study were selected with the consideration of being able to make symbolic representations and verbal representations in problem solving. The process of collecting data in this study begins by giving problems to the subject. The problem used in this research was "Uncle will distribute 20 candies to Budi, Dian and Anwar. Budi gets 8 candies, Dian gets three times more candies than Anwar. How many pieces candy does Dian get?". After the subject solves the problem, the researcher conducts an interview based on the subject's work. Interviews conducted aim to reveal how the subject can make symbolic representations and verbal representations. In addition, the interview is also to clarify certain parts that have not been known by researchers. In data collection, researchers also use video recorder to record all the subject activity in solving the problem.

\section{Result}

The research data was in the form of symbolic representation and verbal representation made by students during the problem-solving. Referring to the data, it is necessary to encode the symbolic representation and verbal representation first;1) Symbolic representation is characterized by the use of mathematical symbols in solving problems, 2) Verbal representation is characterized by the use of verbal form of sentences in writing in solving the problem.

\section{Finding 1. The Process of Symbolic Representation in Problem Solving.}

Description of Subject 1:

The process of symbolic representation was made by the subject during the understanding of the problem. In understanding the problem, the subject wrote all the information that was in the problem. In addition, subject also wrote symbol $x$ which was used as the variable of the number of candies given to Dian and Anwar whose value was not yet known. Because Dian got candy three times more than Anwar, then symbolized by $3 x$. In addition to writing down the information in the problem, the subject also understood and wrote down what was asked by the problem.

Based on the result to understand the problem, the subject could create a linear equation of one variable that was $4 x+8=20$ ( $4 x$ was obtained from summing the number of candies received by Dian and Anwar symbolized by $3 x$ and $x$ ). Equation $4 x+8=20$ was made by the subject appropriately. The equation had accurately described the problem situation. Based on the equation, the subject could determine the value of $x=3$. Thus, subject could determine the number of candies received by Dian that was Dian received three times more candy than Anwar (symbolized by $3 \mathrm{x}$ ). Therefore Dian received 3 x $3=9$ candies.

To clarify the process of symbolic representation performed by subject 1 , the following is represented the process structure of symbolic representation; 


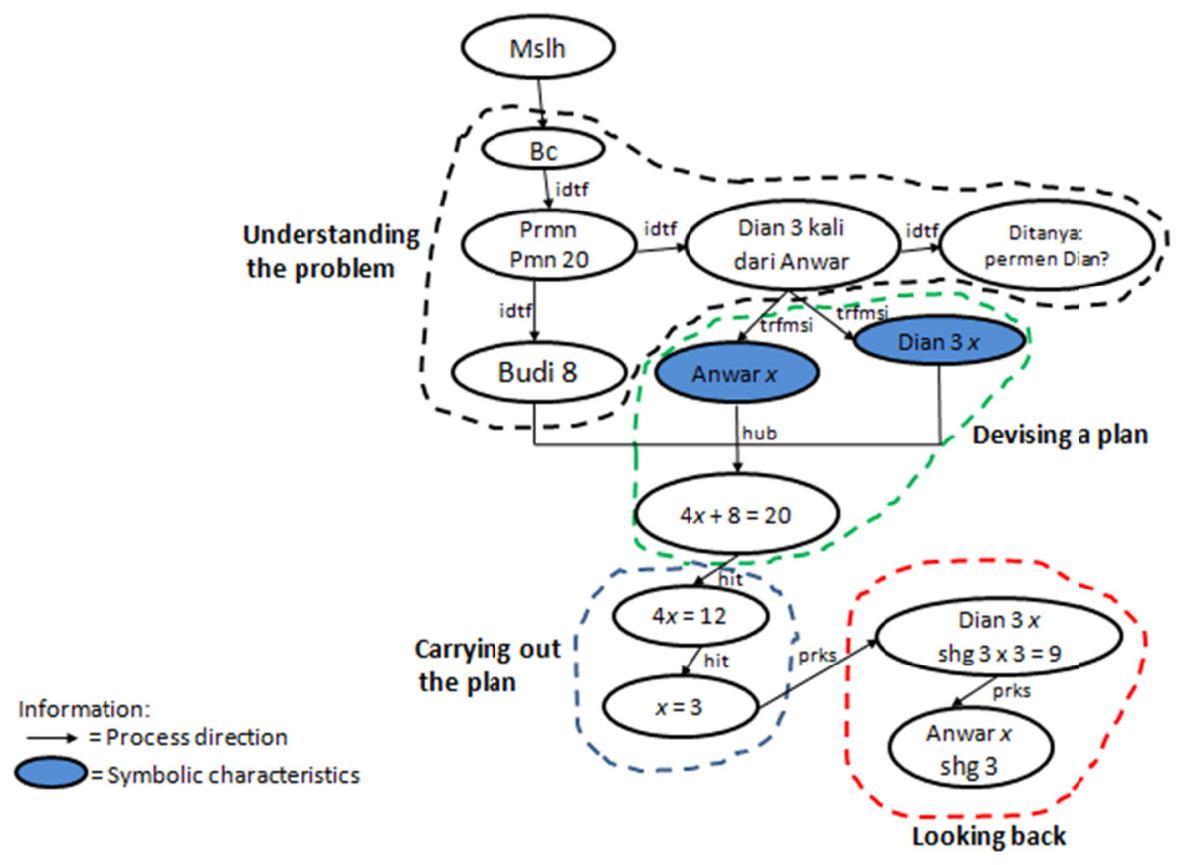

Figure 1. The process structure of symbolic representation of subject 1

Table 1 . The term code of symbolic representation process of subject 1

\begin{tabular}{ll}
\hline Term & Code \\
\hline Identify the problem & idft \\
\hline Transforms into another form & trnfmsi \\
\hline Connecting some information & hub \\
\hline Perform a series of calculations & hit \\
\hline Looking back & prks \\
\hline Problem & Mslh \\
\hline Read the problem & Bc \\
\hline 20 Uncle's Candies & PrmnPmn 20 \\
\hline Dian got candy three times more than Anwar & Dian 3 kali dari Anwar \\
\hline Question in problem & Ditanya: permen Dian? \\
\hline Budi got 8 candy & Budi 8 \\
\hline Candy obtained by Anwar & Anwar $x$ \\
\hline Candy obtained by Dian & Dian $3 x$ \\
\hline Linear equations & $4 x+8=20$ \\
\hline The calculation process to determine the value of $x$ & $4 x=12$ \\
\hline Obtained value $x$ & $x=3$ \\
\hline Enter the value $x=3$ for the amount of candy obtained by Dian & Dian $3 x$ shg $3 \times 3=9$ \\
\hline Enter the value $x=3$ for the amount of candy obtained by Anwar Anwar $x$ shg 3 \\
\hline
\end{tabular}

\section{Description of Subject 2:}

The process of symbolic representation generated by the subject began when understanding the problem. In understanding the problem, the subject wrote symbol $A$ used as the variable of number of candies given to Dian and Anwar. Because Dian got candies three times more than Anwar then it was symbolized by $3 \mathrm{~A}$. Based on the result of understanding the problem, the subject could create a linear equation of one variable namely $8+3 \mathrm{~A}+$ $A=20$ ( $3 \mathrm{~A}$ as the variable of the number of candies received by Dian, while A as the variable of the number of 
candies received by Anwar). Equation $8+3 A+A=20$ was made by the subject appropriately. The equation had accurately been described the problem situation. Based on the equation, the subject could determine the value of $A=3$. Thus, the subject could determine the number of candies received by Dian that was Dian received three times more candies than Anwar (symbolized by 3A). Therefore Dian received 3 x $3=9$ candy.

To clarify the process of symbolic representation performed by subject 2, the following is represented the process structure of symbolic representation;

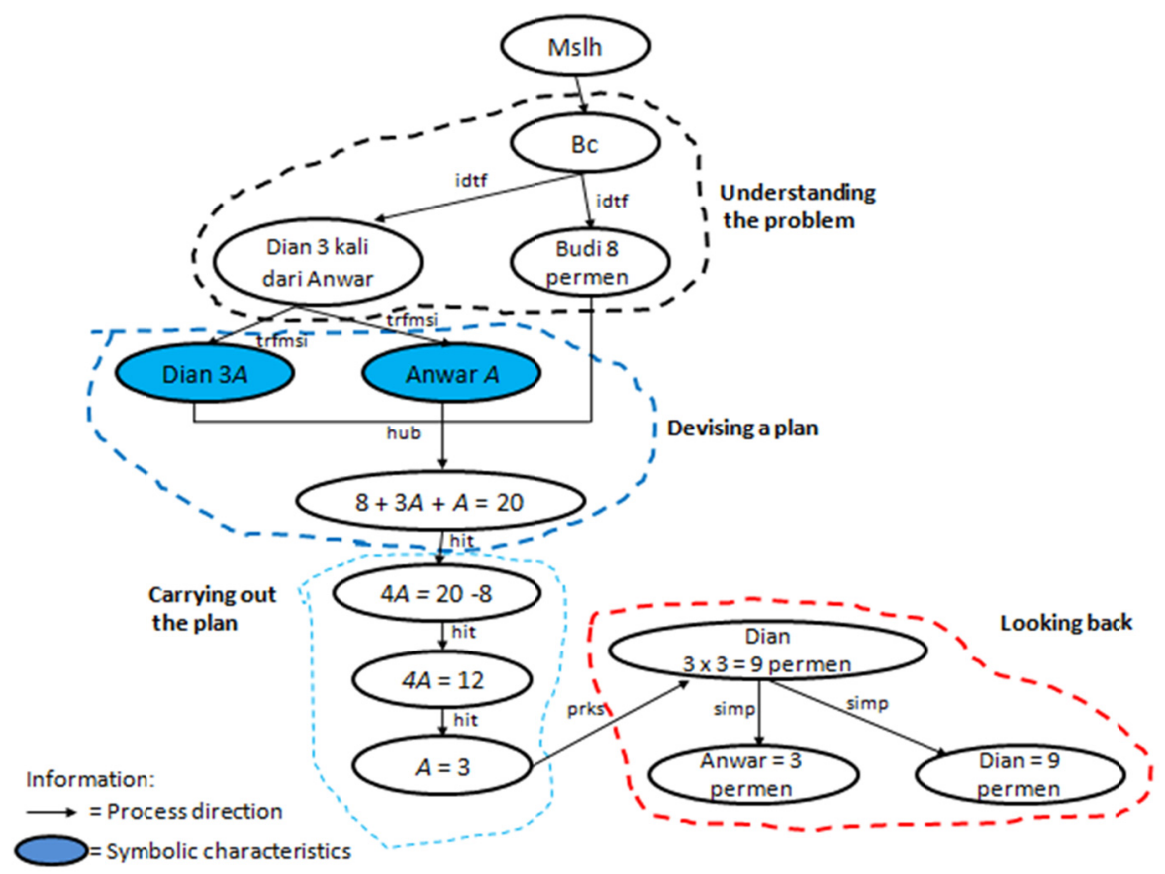

Figure 2. Process structure of symbolic representation of subject 2

Table 2. The term code of symbolic representation process of subject 2

\begin{tabular}{ll}
\hline Term & Code \\
\hline Identify the problem & idft \\
\hline Transform into another form & hub \\
\hline Connecting some information & hit \\
\hline Perform a series of calculations & prks \\
\hline Looking back & Mslh \\
\hline Problem & Bc \\
\hline Read the problem & Simp \\
\hline Write down the conclusion & Dian 3 kali dari Anwar \\
\hline Dian got candy three times more than Anwar & Budi 8 permen \\
\hline Budi got 8 candy & Dian $3 A$ \\
\hline Candy obtained by Dian & Anwar $A$ \\
\hline Candy obtained by Anwar & $8+3 A+A=20$ \\
\hline Linear equations & $4 A=20-8$ \\
\hline The calculation process to determine the value of $A$ & $4 A=12$ \\
\hline The calculation process to determine the value of $A$ & $A=3$ \\
\hline Obtained value $A$ & Dian $=9$ permen \\
\hline Enter the value $A=3$ for the amount of candy obtained by Dian Dian $3 \times 3=9$ permen \\
\hline
\end{tabular}


Finding 2. The Process of Verbal Representation in Problem Solving.

Description of Subject 1:

The process of verbal representation by the subject was made during the process of understanding the problem. In understanding problem, subject wrote down all the information that was in the problem in written. The information obtained and written by the subject was "first, there are 20 candies that will be distributed to Budi, Dian, Anwar. Dian gets 3 times candies than Anwar's ". After subject understood and wrote the information sourced from the problem, subject continued by arranging a plan. In this case subject performed a subtracting operation of $20-8=12$. The purpose of subtracting operation was to describe the situation in the problem, in which there were 20 candies to be distributed to Budi, Dian and Anwar, where Budi got 8 candies. So there were still 12 candies that would be distributed to Dian and Anwar.

Based on the plan prepared by the subject, the remaining were 12 candies. Then subject did the calculation where Anwar got 3 candies, Dian got 3 times candies than Anwar, so Dian got 9 candies. Subsequently the subject checked by summing the candies distributed to Anwar, Dian, and Budi namely $3+9+8=20$.

To clarify the process of symbolic representation performed by subject 1 , the following is presented the process structure of verbal representation;

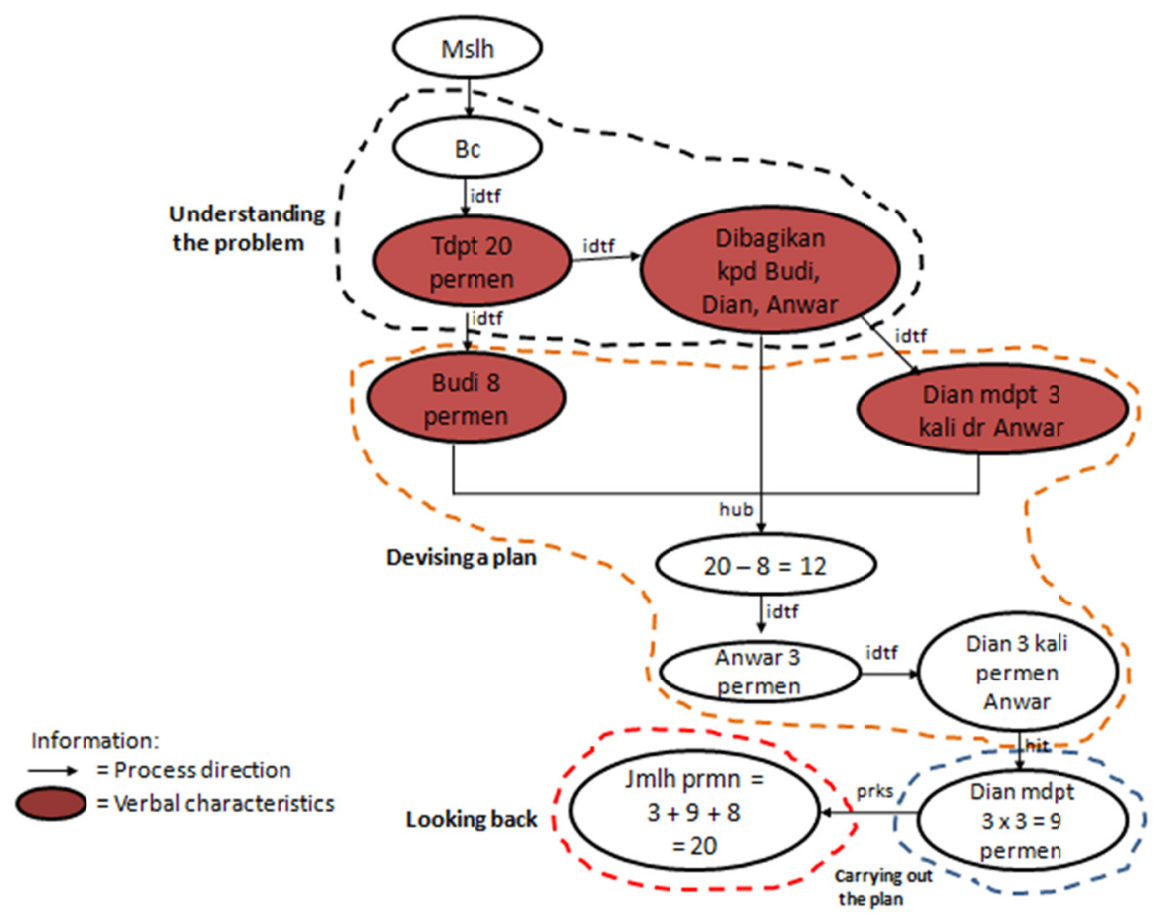

Figure 3. Process structure of verbal representation of subject 1

Table 3. The term code of symbolic representation process of subject 1

\begin{tabular}{ll}
\hline Term & Code \\
\hline Identify the problem & idft \\
\hline Connecting some information & hub \\
\hline Perform a series of calculations & hit \\
\hline Do examination & prks \\
\hline Problem & Mslh \\
\hline Read the problem & Bc \\
\hline There are 20 candies & Tdpt 20 permen \\
\hline 20 candies are distributed to Budi, Dian, Anwar & Dibagikan kpd Budi, Dian, Anwar \\
\hline Budi got 8 candy & Budi 8 permen \\
\hline
\end{tabular}




\begin{tabular}{ll}
\hline Dian got candy three times more than Anwar & Dian mdpt 3 kali dr Anwar \\
\hline Substraction operation & $20-8=12$ \\
\hline Anwar gets 3 candy & Anwar 3 permen \\
\hline Dian got candy three times more than Anwar & Dian 3 kali permen Anwar \\
\hline The candy that Dian receives & Dian mdpt 3 x $3=9$ permen \\
\hline Checking by adding lots of Anwar candies plus Dian candy plus Budi candy Jmlh prmn $=3+9+8=20$ \\
\hline
\end{tabular}

\section{Description of Subject 2:}

The process of verbal representation by the subject was done during the process of understanding the problem. In understanding the problem, subject wrote down all the information that was in the problem written. The information obtained by the subject was "Candies owned by Uncle were 20 pieces, given to Budi 8 pieces". Subject could also understand the question of how many candies received by Anwar and Dian, where Dian got three times more candies than Anwar.

After the subject understood the problem and wrote the information sourced from the problem, he continued by arranging a plan. In this case the subject performed a subtracting operation of $20-8=12$. Then the subject performed calculation using a written sentence, namely: "If Dian gets 3 times candies than Anwar, then Anwar has 3 candies. Because if Anwar has 3 candies and Dian has 3 times than Anwar $=3 \times 3=9$ candies. Furthermore, subject checked and made a conclusion by writing "So, Dian's candies are 9 pieces +3 pieces of Anwar's candies $=12+8$ Budi's candies $=20$.

To clarify the process of symbolic representation done by subject 2, the following is presented the process structure of verbal representation;

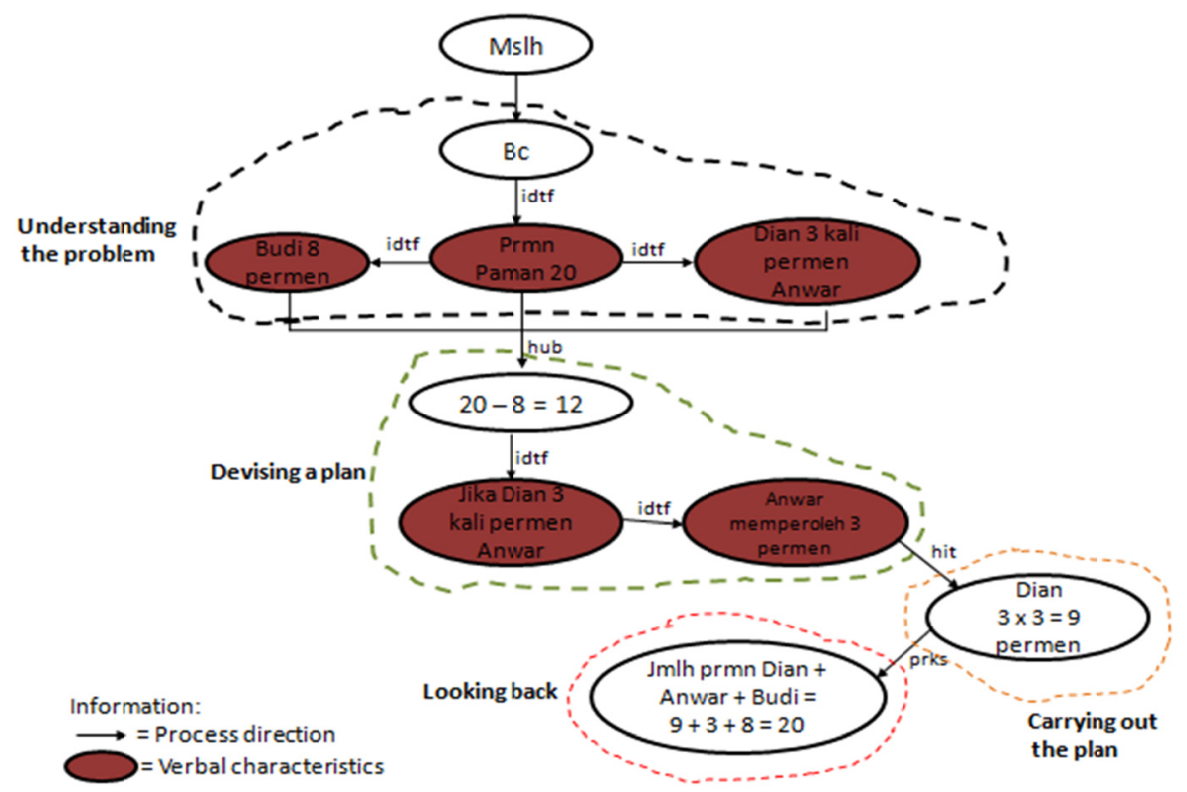

Figure 4. Process structure of verbal representation of subject 2

Table 4 . The term code of symbolic representation process of subject 2

\begin{tabular}{ll}
\hline Term & Code \\
\hline Identify the problem & idft \\
\hline Connecting some information & hub \\
\hline Perform a series of calculations & hit \\
\hline Do examination & prks \\
\hline Problem & Mslh \\
\hline
\end{tabular}




\begin{tabular}{ll}
\hline Read the problem & Bc \\
\hline Uncle will distribute 20 candies & Prmn Paman 20 \\
\hline Budi got 8 candy & Budi 8 permen \\
\hline Dian got candy three times more than Anwar & Dian 3 kali permen Anwar \\
\hline Substraction operation & $20-8=12$ \\
\hline Perform calculations using sentences & Jika Dian 3 kali permen Anwar \\
\hline E.g. Anwar get 3 candy & Anwar memperoleh 3 permen \\
\hline So Dian get 9 candy & Dian 3 x 3 =9 permen \\
\hline Checking by adding lots of Dian candies plus Anwar candy plus Budi candy Jumlh prmn Dian + Anwar + Budi $=9+3+8=20$ \\
\hline
\end{tabular}

\section{Discussion}

This research described the construction process of symbolic and verbal representations done by students in problem solving. The first findings show that the research data specifically indicates the symbolic representation made by the students at the stage of understanding the problem. The students with symbolic representation used the symbol $x$ and $A$ was used as an information variable that the value was unknown. Based on these symbol, students could make the equations $4 x+8=20$ and $8+3 A+A=20$. The equations generated by the student had precisely matched the problem situation that was in the source of the problem. It was in accordance with the opinion of Lesh et al. (1987) that the skill of symbolic representation is characterized by the skill in transforming mathematical problems into the representation of arithmetic formulas. The symbol was used effectively by students in problem solving. The symbol simplified the problem solving process. This finding was in accordance with the opinion of Dahlan and Juandi (2016) that in high school students, representations are useful for solving problems or clarifying, or expanding mathematical ideas starting from the process of collecting facts (data), arranging tables or graphs, until the development of symbolic representation (algebra). In addition, the result of this study also supports Schoenfeld's theory (in Stylianou, 2010) that representation is as a means to understand the information obtained in problem situations. Someone uses representation as a means to combine different aspects of the problem so that all obstacles can be seen and how they interact. This is an important function of representation since not all aspects of the problem situation can be readily captured by the readers.

The second finding showed that verbal representation was made by students at the stage of understanding the problem. Based on the student worksheet it appeared that students with verbal representations wrote down all the information that was in the problem with little change according to what they understood from the source of the problem. Based on the information they obtained in understanding the problem, students could perform a subtracting operation of $20-8=12$. The subtracting operation described the problem situation that existed on the source of the problem. Based on the results of the subtracting operation the students could perform a series of calculations to solve the problem. The calculation performed by the students did not involve the formal operation of mathematical calculations. However, students were more dominant to use sentences in writing to solve the problem. The result was consistent with the opinion of Lesh et al. (1987) that the procedure in solving the problem, one of them can be done by explaining the problem solution by using verbal (written) or oral (speech). Besides Kaput (1987), Lesh (1987), Zhang (1997) Johnson (1998), and Milrad (2002) explain that language representation skills (verbal) are characterized by a passion in translating the nature and relationships in mathematical problems into verbal or verbal representations. The verbal representation used by students is very effective in problem solving. This is supported by the opinion of Hwang et al. (2007) that students who are skilled in manipulating translation between representations using their language are students who have good problem-solving skills.

\section{Conclusion}

Based on the results of this study it can be concluded that the construction process of symbolic representation done by students starts since at the stage of understanding the problem. In understanding the problem, students are able to identify the problem well so that students can make the symbol used as a variable that the value has not known yet. Symbols created by students are very helpful and facilitate students in solving problems. While in the construction process of verbal representation is also done by students at the stage of understanding the problem. The form of verbal representation is manifested by writing down all known information from a slightly changed problem because they use a language that they understand more. Based on known information, students can plan and perform a series of calculations using written sentences so that problems can be solved properly. 


\section{References}

Akkus, O., \& Cakiraglu, E. (2006). Seventh Grade Students' Use of Multiple Representations in Pattern Related Algebra Tasks. Hacettepe Üniversitesi Eitim Fakültesi Dergisi, 31, 13-24.

Anwar, R., B., Yuwono, I., Asari, A., R., Sisworo, \& Rahmawati, D. (2016).Mathematical Representation by Students in Building Relational Understanding on Concepts of Area and Perimeter of Rectangle. Educational Research and Reviews, 11(21), 2002-2008. https://doi.org/10.5897/ERR2016.2813

Bal, A. P. (2014). The Examination of Representations Used by Classroom Teacher Candidates in Solving Mathematical Problems. Educational Sciences: Theory\&Practice. https://doi.org/10.12738/estp.2014.6.2189

Boonen, J. H. A., Wesel, F. V., Jolles, J., \& Schoot, M. V. D. (2014). The Role of Visual Representation Type, Spatial Ability, and Reading Comprehension in Word Problem Solving: An Item-Level Analysis in Elementary School Children. International Journal of Educational Research, 68, 15-26. https://doi.org/10.1016/j.ijer.2014.08.001

Cai, J. (2005). US and Chinese Teachers' Constructing, Knowing and Evaluating Representations to Teach $\begin{array}{lllll}\text { Mathematics. Mathematical Thinking and Learning, } & \text { 7, }\end{array}$ https://doi.org/10.1207/s15327833mt10702_3

Çelik, D., \& Arslan, A. S. (2012).The Analysis of Teacher Candidates' Translating Skills in Multiple Representations. Elementary Education Online, 11(1), 239-250.

Cobb, P. (2003). Modeling, Symbolizing, and Tool Use in Statistical Data Analysis. In K. Gravemeijer, R. Lehrer, B. van Oers, \& L. Verschaffel (Eds.), Symbolizing, modeling and tool use in mathematics education. Dordrecht, The Netherlands: Kluwer.

Cobb, P., Stephen, M., McClain, K., \& Gravemeijer, K. (2002). Participating in Classroom Mathematical Practices. The Journal of the Learning Sciences, 10(1\&2), 113-163.

Creswel, J. W. (2012). Educational Research: planning, conducting, and evaluating quantitative and qualitative research (4th ed.). Boston, USA: Pearson.

Dahlan, J. A., \& Juandi, D. (2011).Analisis Representasi Matematik Siswa Sekolah Dasar Dalam Penyelesaian Masalah Matematika Kontekstual. Jurnal Pengajaran MIPA, 16(1), 128-138. https://doi.org/10.18269/jpmipa.v16i1.273

Delice, A., \& Sevimle, E. (2010). An Investigation of the Pre-Services Teachers' Ability of Using Multiple Representations in Problem-solving Success. The Case of Definite Integral. Educational Sciences: Theory\& Practice.

Dündar, S. (2015). Mathematics Teacher-Candidates Performance in Solving Problem with Different Representation Style: The Trigonometry Example. Eurasia Journal of Mathematics, Science \& Technology Education, 2015, 11(6), 1379-1397. https://doi.org/10.12973/eurasia.2015.1396a

Gibson, D. (1998). Students' Use of Diagrams to Develop Proofs in an Introductory Analysis Course. CBMS Issues in Mathematics Education, 7, 284-307. Providence, RI: American Mathematical Society. https://doi.org/10.1090/cbmath/007/08

Goldin, G. A. (2002). Representational Systems, Learning, and Problem Solving in Mathematics. Journal of Mathematical Behavior, 17(2), 137-165. https://doi.org/10.1016/S0364-0213(99)80056-1

Goldin, G. A., \& Shteingold, N. (2001).Systems of Representations and the Development of Mathematical Concepts. In A. A. Cuoco \& F. R. Curcio (Eds.), The Roles of Representation in School Mathematics (pp. 1-23). Reston, VA: NCTM.

Gravemeijer, K., Lehrer, R., Van Oers, B., \& Verschaffel, L. (2003). Symbolizing, Modeling and Tool Use in Mathematics Education. Dordrecht, The Netherlands: Kluwer.

Hutagaol, K. (2013). Multi Representasi Dalam Pembelajaran Matematika. KNPM V, Himpunan Matematika Indonesia.

Hwang, W.-Y., Chen, N.-S., Dung, J.-J., \& Yang, Y.-L. (2007). Multiple Representation Skills and Creativity Effects on Mathematical Problem Solving using a Multimedia Whiteboard System. Educational Technology \& Society, 10(2), 191-212.

Izsak, A. (2003). "We Want a Statement That is Always True": Criteria for Good Algebraic Representations and the Development of Modeling Knowledge. Journal for Research in Mathematics Education, 34(3), 191-227. 
https://doi.org/10.2307/30034778

Johnson, S. (1998). What's in a representation, why do we care, and what does it mean? Examining evidence from psychology. Automation in Construction, 8(1), 15-24. https://doi.org/10.1016/S0926-5805(98)00062-4

Kaput, J. J. (1987).Representation systems and mathematics. In C. Janvier (Ed.), Problems of Representation in the Teaching and Learning of Mathematics (pp. 19-26). Hillsdale, NJ: Erlbaum.

Kaput, J. J., Noss, R., \& Hoyles, C. (2008). Developing new notations for a learnable mathematics in the computational. In L. English (Ed.), Handbook of international research in mathematics education (2nd ed., pp. 693-715). New York: Routledge/Taylor \& Francis.

Kilpatrick, J., Swafford, J., \& Findell, B. (Eds.). (2001). Adding it up: Helping children learn mathematics. Washington, DC: National Academy Press.

Lesh, R., Post, T., \& Behr, M. (1987). Representations and translations among representations in mathematics learning and problem solving. In C. Janvier (Ed.), Problems of Representation in the Teaching and Learning of Mathematics (pp. 33-40). Hillsdale, NJ: Erlbaum.

Meira, L. (2003). Mathematical Representations as Systems of Notations-in-use. In K. Gravemeijer, R. Lehrer, B. van Oers, \& L. Verschaffel (Eds.), Symbolizing, modeling and tool use in mathematics education (pp. 87-104). Dordrecht, The Netherlands: Kluwer.

Milrad, M. (2002).Using Construction Kits, Modeling Tools and System Dynamics Simulations to Support Collaborative Discovery Learning. Educational Technology \& Society, 5(4), 76-87.

National Council of Teachers of Mathematics (NCTM). (2000). Principles and Standards for School Mathematics. United States of America: The National Council of Teachers of Mathematics, Inc.

Newell, A., \& Simon, H. (1972). Human Problem Solving. Englewood Cliffs, NJ: Prentice Hall.

Polya, G. (1973). How to Solve It: A New Aspect of Mathematical Method (2nd ed.). New Jersey: Pricenton University Press.

Stylianou, D. A. (2008). Representation as a Cognitive and Social Practice. In O. Figueras (Ed.), Proceedings of the joint meeting of the 32nd Annual Meeting for the Psychology of Mathematics Education and Psychology of Mathematics Education - North America (Vol. 4, pp. 289-296). Mexico, Morelia: Centro de Investigacio'n y de Estudios Avanzadosdel IPN and Universidad Michoacana de San Nicolas de Hidalgo. https://doi.org/10.1007/s10857-010-9143-y

Stylianou, D. A. (2010). Teachers' Conceptions of Representation in Middle School Mathematics. Journal of Mathematics Teacher Education, 13, 325-343. https://doi.org/10.1207/s15327833mt10604_1

Stylianou, D. A., \& Silver, E. A. (2004). The Role of Visual Representations in Advanced Mathematical Problem Solving: An Examination of Expert-Novice Similarities and Differences. Journal of Mathematical Thinking and Learning, 6(4), 353-387.

Villegas, J. L., Castro, E., \& Gutierrez, J. (2009). Representation in Problem Solving: A Case Study with Optimization Problem. Electronic Journal of Research in Education Psychology, 17(7), 279-308.

Zhang, J. (1997). The nature of external representations in problem solving. Cognitive Science, 21(2), 179-217. https://doi.org/10.1207/s15516709 $\operatorname{cog} 2102 \_3$

\section{Copyrights}

Copyright for this article is retained by the author(s), with first publication rights granted to the journal.

This is an open-access article distributed under the terms and conditions of the Creative Commons Attribution license (http://creativecommons.org/licenses/by/4.0/). 